\section{Hydrogeochemical characteristics of an old mine adit in the Harz Mountains (Germany)}

\section{MAREIKE BOTHE-FIEKERT, ELKE BOZAU AND WILFRIED LIESSMANN}

\section{TU Clausthal}

Presenting Author:mbf13@tu-clausthal.de

The former Pb-Zn-mine "Grund" was the most important ore mine in the Upper Harz region. To drainage the mine, the adit "Ernst-August-Stollen" was built from 1851-1864. It is the youngest, largest, and deepest drainage adit of the Harz Mountains. In addition to the Grund mining districts, the adit with a length of $40 \mathrm{~km}$ also drains the mining districts Silbernaal, Wildemann, Zellerfeld, Clausthal, Bockswiese and Lautenthal. Although mining ended, in the other localities about 100 years ago, the adit is still active. During a hydrogeochemical study in 2020, water samples were taken at the portal in Gittelde for a period of 7 weeks. Field parameters (temperature, specific electrical conductivity/SEC, $\mathrm{pH}$ ) were determined. The samples were filtered through a $0.45 \mu \mathrm{m}$ Millipore membrane filter and examined for major elements using ion chromatography and analyzed for trace elements using ICP-MS. The concentrations follow the general trend $\left[\mathrm{Na}^{+}\right]>\left[\mathrm{Ca}^{2+}\right]>\left[\mathrm{Mg}^{2+}\right]>\left[\mathrm{K}^{+}\right]$. Compared to other water analyses of the Harz region, the waters of the adit show an excess of sodium. This could be explained by various assumptions: One possible cause is the backfilling with concrete of the mined ore deposits. Another source could be the weathering of the surrounding carboniferous strata like greywacke. Furthermore, higher concentrations of strontium and barium were established. These concentrations are due to the Permian strata and the occurrence of hydrothermal barite veins [1]. Even though the chemical composition of the adit water at the portal is nearly constant, slight evaporation effects during dry periods that led to an increase in electrical conductivity were observed (Figure 1). During an inspection of the adit an old oil separator as a relict of the ore processing in the Grund mine was discovered (Figure 2). This oil separator contains a large amount of iron precipitations. A solid sample was taken and first analyses with $\mathrm{x}$-ray diffractometry indicated the mineral phases goethite, gypsum and calcite. Water samples taken in and near the oil separator showed much higher concentrations compared to the other water samples of the adit.

[1] Harz, westlicher Teil; Mohr, K. (1998).5. erg. Aufl. G. Borntraeger, Berlin.
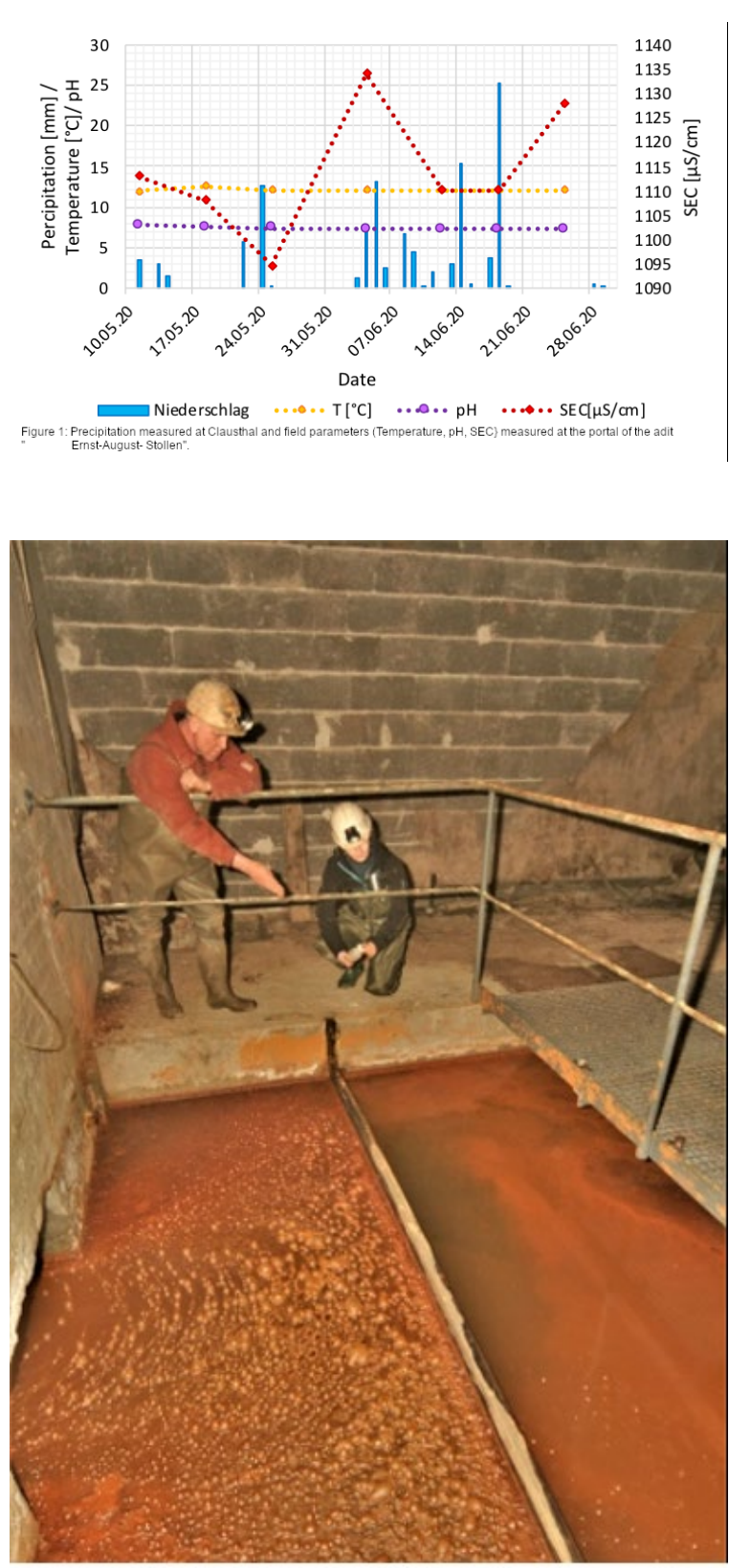

Figure 2: Oil seperator at the "Achenbach" shaft in the level of $180 \mathrm{~m}$ (m.a.s.I.) "Ernst-Auqust-Stollen". 